\title{
Measuring the Effects of World Oil Price Change on Economic Growth and Energy Demand in Malaysia: An ARDL Bound Testing Approach
}

\author{
Nora Yusma Bt. Mohamed Yusoff and Nurul Wahilah Bt. Abdul Latif
}

\begin{abstract}
This paper investigates the effects of world oil price change on economic growth and energy demand in Malaysia by using an ARDL bounds testing co-integration approach. The results revealed that changes in world oil price benefitted the Malaysia's real GDP in the short term. Interestingly, the estimated results showed that energy demand is found to be an oil price inelastic and income elastic of demand, consistently in the short and long run. In addition to that, there was a bidirectional causality effect between energy demand and GDP, which would have important implications for energy policy, where the energy policy may be implemented without convey adverse effects to both energy sector and economy performance. Given the dominant effects of oil price on energy demand and economic growth, this study suggests that policy planner should confer prompt response and choose the right mechanism of energy conservation and fiscal policy, especially to keep environmental friendly with sound macroeconomic balances. Also, in order to retard the fuel import growth, inter fuel substitution towards indigenous resources, mainly green energy resources would be required critically.
\end{abstract}

Index Terms-ARDL, economic growth, energy demand and oil price.

\section{INTRODUCTION}

The Malaysia economy has been growing steadily in the last several decades. With an annual average growth projected at $4.8 \%$, the demand for energy demand will inevitably increase. During the 8th Malaysia Plan, several strategies were formulated to meet the challenge including the promotion of renewable energy and efficient utilization of resources. Meanwhile in the next Malaysian Plan,the development of the energy sector focuses on the diversification of fuel sources especially nonfossil fuel to reducing the dependency on fossil fuel products. Owing to the importance of the energy sector to the Malaysian economy, the National Depletion Policy has been formulated to preserve the Malaysian economy's energy resources, particularly oil and gas resources. The Four-Fuel Policy was introduced to reduce the economy's overdependence on oil and later was expanded to incorporate renewable energy as the fifth fuel after oil, gas, coal and hydroelectric.

Economic growth is a key determinant of energy sector

Manuscript received October 9, 2012; revised February 2, 2013.

M. Y. Nora Yusma and A. L. Nurul Wahilah are both with Department of Finance \& Economics College of Business Management \& Accounting Universiti Tenaga Nasional Sultan Haji Ahmad Shah Campus Pahang, (email: nora@uniten.edu.my, NurulWahilah@uniten.edu.my) growth. Although there is not a one-to one relationship between GDP growth rates and energy demand growth rates, there is a strong positive correlation between energy demand and economic growth in Malaysia from 1966 to 2006 (from First to Tenth Malaysian Plan) where the average annual growth rate of energy demand and real GDP are at 6.67 and 6.4 per cent, respectively. [1]. This means that energy demand typically increases with consistent with increasing in GDP growth. Thus, it is no doubt that energy infrastructure growth has been regarded as indispensable to economic development, and is now the driver and stimulus for greater economic growth in Malaysia.

It was witnessed that rising oil prices especially in 2007 and 2008 had substantially increased government subsidies as the gap between world market prices and the price caps on electricity and petroleum products widened. In fact, Malaysia has had a cap on the price of electricity and petroleum products for almost 10 years. Specifically, Malaysia has been subsidizing its liquefied natural gas (LNG) since January 1990, diesel since October 1999, and petrol since June 2005 [2]. Since then, it has been running a fiscal deficit which has been growing progressively from RM5 billion in 1998 to RM 36.5 and RM48 billion for 2008 and 2009, respectively. Evidently, the fuel subsidy has made a hole in the country's budget, contributing to the fiscal deficit, which stood at 4 per cent of GDP in 2008 and increase to $4.7 \%$ in 2009 , putting pressure on the budget and prompting the Malaysian government to review their subsidy policies. In addition, as a proportion of GDP, Malaysia is one of the world's highest subsidized countries in terms of GDP compared to Indonesia 2.7\%, Philippines $0.2 \%$ and OECD countries at $1.5 \%$ on average in year 2009 [3].

In line with this, recently, under the new Economic Transformation Programs (ETP) Model, a Road Map of Malaysia towards Vision 2020 realizations, the Malaysian government has put great endeavor to rationalize the subsidy reform framework. This is done by resoluting the subsidy reform framework under their one of the 12 National Key Economic Areas (NKEAs). Subsequently, in July 2010 subsidies for petroleum products as well as sugar, have been reduced as the first step in a gradual subsidy rationalization program.

However, the impact of high oil prices on Malaysia's overall economic performance would also depend on the exposure of the Malaysian economy to oil, and the extent of the spillover effect of the increase in costs on other products and services. At the first glance as an oil exporting country, high oil prices would benefit the Malaysian economy as the 
positive gains from higher oil prices would offset any negative impact on the economy.

In this context, this paper attempts to explore the effects of oil price changes on energy demand and economic growth in Malaysia. These tests are useful in assessing the interdependence of energy demand to real income and the world oil price for Malaysian economy. In order to accomplish the empirical analysis, this research will apply the bounds testing (or autoregressive distributed lag, ARDL) co-integration procedure, developed by M. Pesaran and Shin (1997) [4] and further extended by Pesaran et al [5] by using time series data $(1980-2005)$. The rest of the paper is structured as follows. Section 2 presents the past studies. Section 3 presents data sources and research methodology. Section 4 describes the empirical results and findings. Section 5 discusses the Policy Implications and finally Section 6 includes several conclusions and further study's recommendations.

\section{PAST STUDIES}

The relationship between oil price, energy demand and economic growth is now well established in the literature as the direction of causality has significant policy implications. Generally, there are three groups of causality directions findings can be found. First, a large number of studies found unidirectional causality running from energy demand to GDP. For instance, Abosedra and Baghestani (1989) argued that the direct Granger test should be used to determine the direction of this causality. They concluded that for all sample periods tested (1947-1972, 1947-1974, 1947-1979, and 1947-1987); there was a unidirectional causality between GNP and energy demand. [6]. Kraft and Kraft (1978) supported the unidirectional causality from GNP growth in energy demand in the United States of America for the period of 1947-1974.[7].

Secondly, a group of studies that found bi-directional causality. Yang (2000) for example found bidirectional causality between aggregate energy demand and GDP in Taiwan. However, he observed different directions of causality when energy demand was disaggregated into different kinds, including coal, oil, natural gas and electricity. His results implied the importance of analyzing the relationship between different sources of energy demand and GDP [8]. Empirically, the direction of causality between energy demand and economic activities in the developing as well as in the developed countries had been searched by employing the Granger or Sims techniques.

Also in another study, Ebohon (1996) found a simultaneous causal relationship between energy demand and economic growth in Tanzania and Nigeria [9]. The last group comprises of studies that found no causal linkages between energy, or even electricity, consumption and economic growth for instance, Yu and Chai (1988) [10]. Stern (1993) also found the absence of any causality in the United States was also revealed as a part of a larger study including other countries. They tested data for six industrialized countries, and found no significant causal relationship between energy demand and GDP growth and, energy and employment [11]. Erol and Yu (1987) found no relationship between energy and GNP [12].
However, most of these studies had focused primarily on developing economies. The unidirectional causality between energy demand and economic growth seems to be more consistent for these countries. So, the conclusion is that a reliable increasing energy supply is required to meet growing energy demand, and as a result to sustain paths of economic growth. Therefore, a further implication is that energy conservation policies may come into conflict with economic growth. In assessing the oil price effects to energy demand and macroeconomic performance, many researchers have concluded that there is a negative correlation between increases in oil prices and the subsequent economic downturns in the United States. Knut (1989) found an asymmetry between the responses of the GDP and oil-price increases and decreases, concluding that the decreases were not statistically significant. Thus, his results confirmed that the negative correlation between GDP and increases in oilprice was persistent when data from 1985 onwards were included [13]. Most of the studies mentioned above incorporated bivariate models which contain energy and an economic variable for co-integrating relationships and use error correction models to test for granger causality.

Other studies also used bivariate models, for instance Nachane et al (1988) [14], Glasure et al (1997) [15], and Cheng and T.W. Lai (1997) [16]. Aside from the bivariate models there were a few studies that utilized multivariate models that allow for more than two variables in the cointegrating relationships, (see example Mehrara (2007) [17] and Mahadevan and Adjaye (2007) [18]. The most common variables used were total primary energy demand and real GDP, but many studies also looked at specific sectors and energy forms (e.g. industrial, residential and transportation sector or coal, oil, gas and electricity consumption). Only a few studies included energy prices (including oil prices) as a third variable, but most of them used the consumer price index as a proxy, for instance Masih and Masih (1996) [19] and Adjayae (2000) [20].

\section{Data Sources ANd Research Methodology}

\section{A. Data}

This study uses annual data from the year (1980 to 2010) period to examine both short run and long run relationships between real growth domestic product (LRGDP), energy demand (LEND), oil prices (LOILP) and employment (LEMP) for Malaysia. Yearly data on real GDP was measured in constant price (2000 as a base year), denominated in US Dollars and energy demand was measured in kt of oil equivalent (ktoe).

Real GDP and energy demand were taken from the World Bank database (www.worldbank.com). Meanwhile, Employment of millions of people and world oil prices dominated in US Dollars in constant price (2000 as base year), were taken from Economic Planning Unit Malaysia (www.epu.gov.my). All data series were transformed into a logarithm form in order to standardize the different units of measurement.

\section{B. Research Instrument}

The models in this study have been estimated by using the bounds testing (or autoregressive distributed lag, ARDL) co- 
integration procedure. Basically, the ARDL method of cointegration analysis is unbiased and efficient. This is because it performs well in small sample size which is also the case in this study (30 observations).

It is also applicable irrespective of whether the underlying variables are integrated of $I(1)$ or $I(0)$. We can also estimate the long run and short run components of the model simultaneously. The ARDL method can distinguish dependent and explanatory variables. The data analysis will be conducted by using Microfit 5 software.

\section{Methodology}

The first step of this analysis is to treat the model as a system of first-difference equations, then the variables must be tested for stationary processes. The ARDL bounds testing procedure can be applied irrespective of whether the variables are I (0) or I (1). In this study, the stationary test of Augmented Dickey and Fuller (ADF) test will be used to test whether $\alpha=0$, therefore the null and alternative hypothesis of unit root tests can be written as follows:

Ho: $\alpha=0$ ( $Y_{t}$ is non-stationary)

Ha: $\quad \alpha<0$ ( $Y_{t}$ is stationary or non unit root)

The unit root hypothesis using the ADF test can be rejected if the calculated pseudo-t value (ADF statistics) lie to the left of the relevant critical value or alternate hypothesis is that $\alpha$ is less than zero $(\alpha<0)$, meaning that the variable to be estimated is stationary. However, normally after taking first differences, the variable will be stationary [21].

The next step is to test for the presence of the long run relationship through the bounds testing approach to estimate the long run relationship between LRGDP, LEND, LOILP and LEMP in equation (1) and equation (2). The last step is to estimate the association of ARDL error correction models.

TABLE I: HYPHOTHESIS

\begin{tabular}{|c|c|}
\hline $\begin{array}{c}\mathrm{H}_{0} \text { (No long run } \\
\text { relationship) }\end{array}$ & $\begin{array}{c}\mathrm{H}_{1} \text { (A long run } \\
\text { relationship) }\end{array}$ \\
\hline \hline $\mathrm{n}_{11}=\mathrm{n}_{12}=\mathrm{n}_{13}=\mathrm{n}_{14}=0$ & at least one $\mathrm{n}_{\mathrm{ij}} \neq 0$ \\
\hline $\mathrm{n}_{21}=\mathrm{n}_{22}=\mathrm{n}_{23}=\mathrm{n}_{24}=0$ & at least one $\mathrm{n}_{\mathrm{ij}} \neq 0$ \\
\hline
\end{tabular}

\section{Model Specification}

In this study we focus only in two models which are Energy Demand Model (LEND) and Real GDP Growth Model (LRGP) in order to assess the impact of world oil price change in energy demand and income for short run and long run effects. The error correction model representation of the ARDL model can be written as follows:

$$
\begin{aligned}
& \Delta \ln \mathrm{END}_{\mathrm{t}}=\beta_{0}+\sum_{\mathrm{j}=1}^{\mathrm{k}} \beta_{11} \Delta \ln \mathrm{END}_{\mathrm{t}-\mathrm{j}}+\sum_{\mathrm{j}=0}^{\mathrm{k}} \beta_{12} \Delta \ln \mathrm{RGDP}_{\mathrm{t}-\mathrm{j}}+ \\
& \sum_{\mathrm{j}=0}^{\mathrm{k}} \beta_{13} \Delta \ln \mathrm{OILP}_{\mathrm{t}-\mathrm{j}}+\sum_{\mathrm{j}=0}^{\mathrm{K}} \beta_{14} \Delta \ln \mathrm{EMP}_{\mathrm{t}-\mathrm{j}}+\mathrm{n}_{11} \ln \mathrm{END}_{\mathrm{t}-1}+\mathrm{n}_{12} \\
& \ln \mathrm{RGDP}_{\mathrm{t}-1}+\mathrm{n}_{13} \ln \mathrm{OILP}_{\mathrm{t}-1}+\mathrm{n}_{14} \ln \mathrm{EMP}+\xi_{\mathrm{t}} \\
& \Delta \ln \operatorname{RGDP}_{\mathrm{t}}=\beta_{0}+\sum_{\mathrm{j}=1}^{\mathrm{k}} \beta_{21} \Delta \ln \operatorname{RGDP}_{\mathrm{t}-\mathrm{j}}+\sum_{\mathrm{j}=0}^{\mathrm{k}} \beta_{22} \Delta \ln \mathrm{END}_{\mathrm{t}-\mathrm{j}}+ \\
& \sum_{\mathrm{j}=0}^{\mathrm{k}} \beta_{23} \Delta \ln \mathrm{OILP}_{\mathrm{t}-\mathrm{j}}+\sum_{\mathrm{j}=0}^{\mathrm{K}} \beta_{24} \Delta \ln \mathrm{EMP}_{\mathrm{t}-\mathrm{j}}+\mathrm{n}_{21} \ln \mathrm{RGDP}_{\mathrm{t}-1}+\mathrm{n}_{22} \\
& \ln \mathrm{END}_{\mathrm{t}-1}+\mathrm{n}_{23} \ln \mathrm{OILP}_{\mathrm{t}-1}+\mathrm{n}_{24} \ln \mathrm{EMP}+\xi_{\mathrm{t}}
\end{aligned}
$$

The terms with the summation signs in the above equations represents the error correction dynamics while the second part (terms with $\eta_{\mathrm{ijs}}$ ) corresponds to the long run relationship; $\Delta$ denotes a first difference operator; ln represents a natural logarithmic; $\beta_{0}$ is an intercept and $\xi_{\mathrm{t}}$ is a white noise. In other hand, the F-test or Wald test is used to test for the existence of long run relationship. If the computed F-test is higher than the upper bound, the null hypothesis of no co-integration is rejected. If the F-test is lower than the lower bound than the null hypothesis cannot be rejected. Meanwhile, if the F-test lies between the lower and the upper bounds, conclusive decision inference cannot be made. Once the co-integration is confirmed, the further two step procedure in ARDL is taken to estimate the models.

\section{EMPIRICAL RESULTS AND FINDINGS}

We have estimated the short run and long run relationships between oil price, energy demand, real GDP and employment. These estimations are presented step by step as follows:

\section{A. Unit-Root Tests}

Table II shows that all variables have a unit root in their level, since the $p$-value for all series are not significant at all levels. Based on these estimated result we failed to reject the null hypothesis of unit roots even at the $10 \%$ significance. However, when we perform the unit root test at first difference, I $(1)$, the results indicate that all variables are I ( 1$)$ since the $P$-value is significant at $1 \%$ and $5 \%$. This means that after we have taken the first difference of all variables, there is no evidence of the existence of unit roots. Interestingly, however, first differences of all the variables show stationary under this test.

TABLE II: RESULTS OF ADF TESTS

\begin{tabular}{|l|c|c|}
\hline \multicolumn{3}{|c|}{ ADF } \\
\hline Variables & Level & 1st Diff \\
\hline LRGDP & -2.385441 & $-5.064396^{* * *}$ \\
\hline LEND & -2.958903 & $-6.677150 * * *$ \\
\hline LOILP & 0.735199 & $-4.120358^{* * *}$ \\
\hline LEMP & -2.577672 & $-5.880473 * * *$ \\
\hline \multicolumn{2}{|c|}{ Note: ***,*** denotes sig. level of $10 \%, 5 \%, 1 \%$, respectively }
\end{tabular}

\section{B. ARDL Bounds Test for Long Run Analysis}

The results of the ARDL bounds test in regard to Malaysia are reported in Table 3. In the LEND and LRGDP model, with LEND and LRGDP as dependent variables, we note that the computed F-statistics for Malaysia is above the upper bound critical values provided by Narayan (2005) [22]. Hence, we have strong evidence to reject the null

\begin{tabular}{|c|c|c|}
\hline F-statistics & $\begin{array}{c}\text { LEND Model } \\
4.4608^{* *}\end{array}$ & $\begin{array}{c}\text { LRGDP Model } \\
9.2718 * * *\end{array}$ \\
\hline $1 \% \mathrm{I}(0)$ & 4.614 & 4.614 \\
\hline $\mathrm{I}(1)$ & 5.966 & 5.966 \\
\hline $5 \% \mathrm{I}(0)$ & 3.272 & 3.272 \\
\hline $\mathrm{I}(1)$ & 4.306 & 4.306 \\
\hline $10 \% \mathrm{I}(0)$ & 2.676 & 2.676 \\
\hline $\mathrm{I}(1)$ & 3.586 & 3.586 \\
\hline
\end{tabular}
hypothesis of no co-integration at $1 \%, 5 \%$ and $10 \%$ significance level, respectively. It shows that there was a long run relationship between LRGDP, LEND, LOILP and LEMP for LRGDP and LEND Model.

TABLE III: BOUNDS TEST RESULTS 
The result was captured by the T-value was 0.002 and 0.015 , respectively and significant at $1 \%$ and $5 \%$ level. These inferred that in the short term, higher oil price would lead to more income for the country. The positive causality means if the world oil price increase it would increase the real GDP in the same direction. However, employment emerge insignificant to the above model. The overall VEC causality results is summarized in Fig. 1.

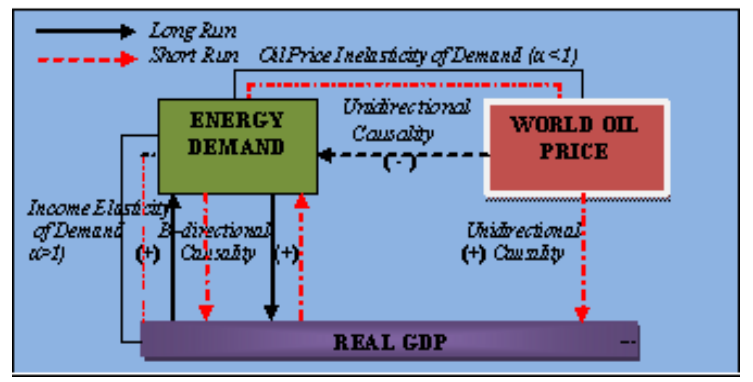

Fig. 1. Effects of World Oil Price Change on Economic Growth and Energy Demand

Fig. 1. shows that there is a positive bidirectional causality running from energy demand to real GDP and real GDP to energy demand, both for short run and long run. The ECM causality test indicated that there is the positive unidirectional causality effect of world oil price on real GDP and negative unidirectional causality effects of oil price to energy demand and the world oil price would become exogenous variables in the Malaysian economy.

In other words, the changes of world oil price give $a$ beneficial impact to real GDP but adverse impact of the energy demand in the short run. Interestingly, the estimated results show that energy demand is found to be an oil price inelastic and income elastic of demand, consistently in the short run and long run, with their coefficient values are in line with the Goldstein-Khan results which lie between [$0.5,-1.0]$ for typical price elasticity and $[1.0,2.0]$ for typical income elasticity.

\section{POLICY IMPLICATIONS}

The direction of causality has significant policy implications. If, for example, there is unidirectional causality running from economic growth to energy demand, it may imply that energy policies may be implemented with little adverse or no effects on economic growth. On the other hand, if unidirectional causality runs from energy demand to income, reducing energy demand i.e. due to higher oil price could lead to income cut or vice versa. If there is 'no causality' in either direction, the co-called 'neutrality hypothesis' would imply that energy policies do not affect economic growth, as in [4]. The estimated result of long run analysis shows that there was a strong relationship between real GDP and energy demand, with a positive sign. These results inferred that the growth rate of national income and energy demand complements each other, which is shown by the positive relationship among them.

However, the coefficient estimates of real GDP in the energy demand Model (Model 1) are slightly higher than parameter estimates of energy demand in GDP Model
(Model 2), which are 0.86 and 0.81 , respectively (refer table 4). This means that energy demand is more depend on GDP rather than GDP depend on energy demand. This result would have important energy policy implications. In another research, Maamor and Sahlan (2005) also found a strong long run relationship between Real GDP and energy demand in Malaysia [23]. These results were also found in other literatures, for instance Ghosh (2002) [26], Fatai et al (2004) [27], Hatemi and Irandoust (2005) [28]. Furthermore, a positive bidirectional causality running from economic growth to total energy demand and vice versa suggests that in the short run energy demand and economic growth complement each other but efficiency policies or other policy would not have any adverse impact to each other. Given the non adverse effects between energy demand and economic growth, better response and right mechanism of energy conservation and fiscal policy should exist to curb the use of non-renewable subsidized energy and to shift extensively inter fuel substitution towards indigenous resources, mainly renewable energy as well as to restore sound macroeconomic balances. In other words, energy conservation policy i.e. energy efficiency policy, green energy policy and energy saving policies may be implemented with little adverse or no harm effects on economic growth in the short run. The findings of this study which is a bidirectional running from real GDP to energy demand also have been supported by the previous research especially in developed countries for instance Soytas and Sari (2003) [29] and Oh and Lee (2004) [30]. They found the bidirectional causality from GNP growth to energy demand and vice versa in the USA for the period of 19471974.

Importantly, the bidirectional causality result also had been supported by the Granger causality analysis, suggested that there could be two-way causality between energy demand growth and economic growth in the future. There could be a similar unidirectional influence from economic growth to disaggregated energy demand and from disaggregated energy demand growth to economic growth [31]. Surprisingly, the most important finding here indicated that the changes in world oil price would have a beneficial impact to Malaysia's real GDP in the short term but not in the long term.

TABLE VI: REAL GDP AND FISCAL COMPONENTS FROM OIL 2005-2010 (RM BILLIONS)

\begin{tabular}{l|c|c|c|c|c|c}
\hline & 2005 & 2006 & 2007 & 2008 & 2009 & 2010 \\
\hline Real GDP & 4493 & 4755 & 5049.2 & 5283 & 5192.2 & 5596 \\
\hline Total Revenve & 106.3 & 123.5 & 139.9 & 159.8 & 158.6 & 160.9 \\
\hline Revenves from Oi1* & 31 & 45.5 & 51.1 & 67 & 68.8 & 68 \\
\hline Fuel Subsidies & 9.717 & 10.86 & 10.437 & 8.1 & 7.89 & na \\
\hline Total Subsidies & 11.85 & 14.48 & 14.7 & 16.2 & 26.3 & $48.41^{* \#}$ \\
\hline Fvel Subsidies/Oil Revenves (\%) & 31.35 & 23.87 & 20.42 & 12.09 & 11.47 & na \\
\hline Oil Revenve/Total Revenve (\%) & 29.16 & 36.84 & 36.53 & 41.93 & 43.38 & 42.26 \\
\hline Fvel subsidies/Rea1 GDP (\%) & 0.216 & 0.228 & 0.207 & 0.153 & 0.152 & na \\
\hline Oil Revenve/Real GDP (\%) & 0.690 & 0.957 & 1.012 & 1.268 & 1.325 & 1.215 \\
\hline \multicolumn{7}{|c|}{ Note : *Oil tax, royalty and dividend and export duty } \\
\hline **The figures include other transfer payments \& edvcation subsidies \\
\hline Source : www.epv.com.my and Ministry of Finance Malaysia \\
\hline
\end{tabular}

However, the insignificant of oil price changes affect to the Malaysia's GDP for long term analysis also have been supported by other studies of oil price effects in Malaysia, but they found the insignificant result in the short term [32]. 
The significant difference in findings for short term analysis could be that the authors used different methodology which was VECM and covered only in year 1980 to 2005 (less than 30 years) whereas our research use ARDL approach, which is more robust to capture a small sample size of the analysis. The difference of five year time series also carried varies significant result, especially during rising world oil prices in the year 2007 and 2008.

Furthermore, the impact of high world oil prices would also depend on the degree of the exposure of the Malaysian economy to oil (as Malaysia is a small oil exporting countries), especially in the case of fuel subsidies economy that could lessen the worst effects on household energy and non energy demand and also depends on energy elasticity of demand, especially for short term and in the long term effects.

As an oil exporting country, high oil prices in the short term, especially for the year 2005 to 2009, where crude oil price has increased sharply from USD57 to USD 95 per barrel, the latter would benefit from slightly higher crude oil price. (Refer Table 6). Thus, volatility in crude oil prices i.e. positive shocks have proven gives a beneficial impact on the Malaysia economy, as it has to other oil producing countries.

This is also being supported by earlier findings by Villafuerte and Murphy (2009) which focused on the 31 Oil Producing Countries (OPCs). The studied found that oil revenue is a critical source of fiscal revenue where fiscal oil revenue accounted for more than $25 \%$ of total fiscal revenue over the (2005-2008) period [33]. In the case of Malaysia, oil revenue has contributed $29.2 \%$ up to $42 \%$ of total revenue for the (2005-2008) period. (Refer Table 6.)

Furthermore, it is found that crude oil is the Malaysia's biggest mineral export accounting for about 5\% (RM32 billion) of total exports in the year 2011. Petroleum related income is the largest single contributor to the government revenue. It accounted about $33.9 \%$ or RM62.9 billions of government's total revenue in 2011. In 2009, it reached its highest level at almost $40 \%$ or RM 68.8 billions. This latter would also help to narrow the deficit gap for Malaysia. Moreover, the positive gains from slightly higher oil prices could also offset any adverse impact to the economy. This is done through pump priming whereby revenue from higher oil prices can be channeled back into the domestic economy through government expenditure via fuel subsidies and later increase others sectors output contribution.

In other words, gaining income from oil revenue from slightly higher oil price is larger than the amount of fuel subsidies that government has to bear. (Refer Table 6 and Fig. 2). Fig. 2 shows that the revenue growth rate is on average at 9.5 per cent of the (2000-2010) period while the average expenditure growth rate for the (2000-2010) was slightly below then revenue ( 9 percent). In terms of per oil revenue, fuel subsidies accounted for $31.4 \%$ of oil revenues for the year 2005 and decrease to $12.1 \%$ and $11.5 \%$ for the year 2008 and 2009, respectively. It also shows that fuel subsidy per real GDP also have decreased from $0.22 \%$ in the year (2005) to $0.153 \%$ and $0.152 \%$ for the year (20082009), respectively. (Refer Table 6).

The non adverse effects of higher oil price to real GDP growth in the short term also could be explained by the implementation of several government policies. For instance, the monetary policy that relates to attain an appropriate balance between maintaining price stability has able to absorb the adverse effects of oil price shocks as well as achieving the maximum sustainable level of economic growth. While fiscal policy that relates to macro-economic policy management i.e. price mechanism, fuel subsidy reforms and tax rebate, has able to help the economy return to the right track with sound macroeconomic balance.

Furthermore, this could also be explained by the successful fuel rebalancing which significantly decreased Malaysia's oil demand between (1980 and 2002) period. The dramatic shift reduced Malaysia's exposure to oil prices, and provided the foundations for a stable power sector; in turn avoid the severe or adverse impact to nation's real GDP growth.

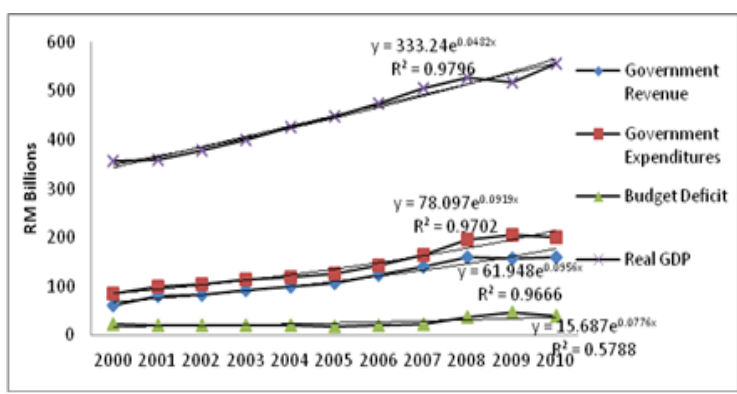

Fig. 2. Revenues, Expenditures, Real GDP and Deficit, 2000-2010 (RM Billion).

Regarding the negative unidirectional causality effects running from oil prices to energy demand, it shows that, in the short term the world oil price changes would have an adverse effect of the energy demand. This result seems to support our expected finding and theoretically correct, as there could be a negative relationship between oil price and energy demand in the short term. Indeed, the negative effects of oil price in energy demand have contributed a beneficial effect which could support the government energy saving and efficiency policy to reduce the carbon emission in the economy. Also, the aggregate energy demand is found to be oil price inelastic demand $(\alpha<1)$ while the value of income elasticity of energy demand is greater than unity (1.77). This would imply that in the short term increase in world oil price have adverse affects to the aggregate energy demand in Malaysia. However, in other hand, the energy demand aggregate is elastic or more sensitive the changes in growth of real output rather than the oil price.

The negative unidirectional causality effects running from oil prices to energy demand in the short term also has indirect effects to real GDP growth. This could be explained by the spillover effects that trigger the economy's response. Increasing the price of energy (i.e. gas and fuel price) in the short term will have two effects: direct and indirect effects on the general price level. The increase of oil price directly increases in the consumer price index (CPI) and causes the indirect effect to the Producer Price Index (PPI) [34]. The industry producers will transfer the increase in the energy prices in their operating cost to the goods and services price. This will trigger macroeconomic effects (i.e. household consumption, government expenditure, investment) in the form of the increases in petroleum product price and other prices of goods and services. This in turn would increase the 
real GDP growth via total aggregate demand (AD) in the economy.

On the other hand, the uncertainty of the oil prices may also affect the consumer expectation as they expect the higher oil price could be long. As a result, in the short term, they will reduce the energy used, and in the long term they probably shift to the inter fuel substitution mainly bio fuel or alternatives. Hence, in the short term, the high oil price will lead a decrease in the non-renewable energy demand.

However, in the long terms the economic system had corrected its previous disequilibrium by responding to this feedback (which showed by the negative value of ECT in Equation 1 and 2) and move towards equilibrium. The reasons could be that when there is an oil price shock or crisis in the economy the government will respond and give feedback to this shock through its various policies mechanisms. For instance, price mechanism control, fiscal stabilizing policies, monetary policies and fuel subsidy policies in order to control the adverse effects to the economy. This in turn could help return the economy to the right track which could lessen the worst impact of the shock to the economy.

\section{CONCLUSIONS AND FUTURE STUDIES}

Given the non-adverse effects between energy demand and economic growth that is bidirectional effects, the study could suggest that for achieving higher economic growth, reducing oil, gas and coal especially in the consumption sectors of the economy would have a beneficial impact on the current account balance via reducing the deficit. The consumption of these non-renewable energies would increase the deficit in Malaysia's balance of payment position of the economy in the future.

Therefore, there should be extensive efforts by all parties in the country to exploit the renewable sources of energy for consumption and production purposes especially in the industrial sector. It has been suggested that in order to reduce the fuel import growth, inter fuel substitution towards indigenous resources, mainly renewable energy would be required critically. One can also undertake a study on the energy use in different sectors and their contribution to the growth of the sector as each sector has the different energy use intensity for different forms of energy use.

\section{REFERENCES}

[1] EPU, "Ninth Malaysian Plan: The Economic Report," The Economic Planning Unit, Prime Minister's Department, Putrajaya, 2006.

[2] The Economic Planning Unit Website. [Online]. Available: http://www.epu.gov.my/

[3] International Energy Agency (IEA), World Energy Outlook: Looking at Energy Subsidies - Getting the Prices Right, International Energy Agency: Paris, 1999.

[4] M. H. Pesaran and Y. Shin, "An Autogressive Distributed Lag Modelling Approach to Cointegration Analysis," Working Paper Trinity College, Cambridge, 1997.

[5] M. H. Pesaran, S. Yongcheol, and R. J. Smith, "Bounds testing approaches to the analysis of level relationships," Journal of Applied Econometrics, vol. 16, pp. 289-326, 2001.

[6] S. Abosedra and H. Baghestani, "New evidence on the causal relationship between U.S. energy demand and Gross National Product," Journal of Energy Development, vol. 14, pp. 285-292, 1989.
[7] J. Kraft and A. Kraft, "On the relationship between energy and GNP," Journal of Energy and Development, vol. 3, pp. 401-403, 1978.

[8] H. Y. Yang, "A note on the causal relationship between energy and GDP in Taiwan," Energy Economics, vol. 22, pp. 309-317, 2000.

[9] O. J. Ebohon, "Energy, economic growth and causality in Developing Countries: A case study of Tanzania and Nigeria," Energy Policy, vol. 24, pp. 447-453, 1996

[10] E. Yu, P. Choi, and J. Chai, "The relationship between energy and employment: A re-examination," Energy System Policy, vol. 11, pp. 287-295, 1988.

[11] D. I. Stern, "Energy and growth in the USA: A multivariate approach," Energy Economics, vol. 26, pp. 463-485, 1993.

[12] U. Erol and E. S. H. Yu, "On the causal relationship between energy and income for industrializing countries," Journal of Energy and Development, vol. 13, pp. 113-122, 1987.

[13] A. M. Knut, "oil and the macroeconomy when prices go up and down: An extension of Hamilton's results," Journal of Political Economy, vol. 91, pp. 740-744, 1989.

[14] D. M. Nachane, R. M. Nadkarni, and A.V. Karnik, "Co-integration and causality testing of the energy-GDP relationship: A cross-country study," Applied Economics, vol. 20, pp. 1511-1531, 1988.

[15] Y. U. Glasure and A. R. Lee, "Co-integration, error correction and the relationship between GDP and energy: The case of South Korea and Singapore," Resource and Energy Economics, vol. 20, pp. 17-25, 1997.

[16] S. B. Cheng and T.W. Lai, "An investigation of co-integration and causality between energy demand and economic activity in Taiwan Province of China," Energy Economics, vol. 19, pp. 435-444, 1997.

[17] M. Mehrara, "Energy demand and economic growth: The case of oil exporting countries," Energy Policy, vol. 35, no. 5, pp. 2939-2945, 2007.

[18] R. Mahadevan and J. A. Adjaye, "Energy demand, economic growth and prices: A reassessment using panel VECM for developed and developing countries," Energy Policy, vol. 35, no. 4, pp. 2481-2490, 2007.

[19] A. M. M. Masih and R. Masih, "Energy demand, real income and temporal causality: Results from a multi-country study based on cointegration and error-correction modeling techniques," Energy Economics, vol. 18, no. 3, pp. 165-183, 1996.

[20] J. A. Adjaye, "The Relationship between energy demand, energy prices and economic growth: Time series evidence from Asian Developing Countries," Energy Economics, vol. 22, pp. 615-625, 2000.

[21] S. Johansen and K. Juselius, "Maximum likehood estimation and inference on co-integration with applications to the demand for money," Oxford Bulletin of Economics and Statistics, vol. 52, 1990 pp. 169-210.

[22] P. K. Narayan, "The saving and investment nexus for China: Evidence from co-integration test," Applied Economics, vol. 37, 2005.

[23] S. Maamor and R. Sahlan, "Energy demand, employment and economic growth in Malaysia: A causality analysis," Malaysia Journal of Economics, vol. 39, pp. 25-52, 2005.

[24] P. Pedroni, "Panel Co-integration: Asymptotic and finite sample properties of pooled time series tests with an application to the Purchasing Power Parity (PPP) hypothesis: New results," Working Papers, University of Michigan, Department of Economics, 2004, pp. $597-625$

[25] M. Goldstein and M. Khan, "Income and Price Effects in Foreign Trade," in Handbook of International Economics, in R. Jones, and P. Kenen, (Ed.), Amsterdam and New York, North-Holland, Elsevier, 1985, vol. 2, pp. 1041-1105,1985

[26] S. Ghosh," Electricity consumption and economic growth in Taiwan," Energy Policy, vol. 30, pp. 125-129. 2002.

[27] K. Fatai, L. Oxley, and F. G. Scrimgeour, "Modeling the causal relationship between energy demand and GDP in New Zealand, Australia, India, Indonesia, Philippines and Thailand," Mathematics and Computers in Simulation, vol. 64, pp. 431-445, 2004.

[28] A. Hatemi and M. Irandoust, "Energy demand and economic growth in Sweden: A leveraged bootstrap approach, 1965-2000," International Journal of Applied Econometrics and Quantitative Studies, vol. 4, pp. 1-20, 2005.

[29] U. Soytas and R. Sari, "Energy demand and GDP: Causality relationship in G7 countries and emerging markets," Energy Economics, vol. 25, pp. 33-37, 2003.

[30] W. Oh and K. Lee, "Causal relationship between energy demand and GDP revisited: The case of Korea 1979-1999," Energy Economics, vol. 26, pp. 51-59, 2004.

[31] C. W. J. Granger, "Developments in the Study of Co-integrated Variables," Oxford Bulletin of Economics and Statistics, 1986, vol. 48, pp. 424-438, 1978. 
[32] H. A. Bekhet and N. Y. Yusof, "Assessing the relationship between oil prices, energy demand and macroeconomics performance in Malaysia: Co-integration and vector error correction model (VECM) approach," Journal International Business and Research, vol. 2, pp. $152-175,2009$.

[33] M. Villafuerte and P. L. Murphy, Fiscal Policy in Oil Producing Countries During the Recent Oil Price Cycle, IMF Working Paper, 2009.

[34] N. M. Ahmad and M. Jusoh, "Impact of Oil Price on Output and Price level in Malaysia," presented at National University Malaysia Conference, Port Dickson, 12-13 October, Malaysia, 2008.

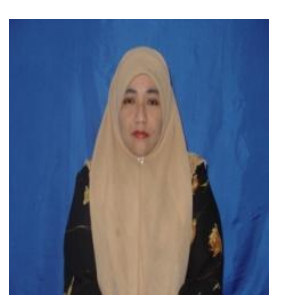

Nora Yusma Binti Mohamed Yusop was born in Kuala Lumpur, Malaysia on 17 August 1971 Currently pursue her Ph.D. studies in Energy Economics (ongoing), University Tenaga Nasional, Putrajaya, Malaysia. Graduated with M.A (Islamic Finance and Economics) (2003) University Malaya, Kuala Lumpur, Malaysia and B.Econs in Economics and Administration(Hons) (1995). Currently she is a Senior Lecturer, at Finance and Economics Department, College of Business and Accounting, Sultan Haji Ahmad Shah Campus26700 Muadzam Shah Pahang Darul Makmur, Malaysia.
Currently she is a member of International Energy Economics Associations (IEEA) of Unites States, a member of the Malaysia Energy Centree (PTM), a member of the Malaysia Economics Associationn (MEA), member of Malaysia Finance and Economics Association. Through joining these associations, she is eligible to subscribe to the many International Journal including International Energy Economics Journals and Economics Journals as well as subscribing Malaysia database for Energy and Economic inputs. She had the opportunities to attend and presenting her research finding at various conferences, workshops, seminars and forum either in Malaysia or abroad.

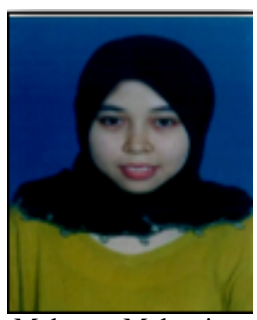

Makmur, Malaysia.
Nurul Wahilah Abdul Latif was born in Perak, Malaysia on $5^{\text {th }}$ January 1975 . She graduated with a Bachelor (Econs.), Economics \& Finance (2000) and Master (Econs.), Financial Economics (2002). Both degrees are from University Kebangsaan Malaysia. Currently she is a Senior Lecturer, at Finance and Economics Department, College of Business and Accounting, Sultan Haji Ahmad Shah Campus 26700 Muadzam Shah Pahang Darul 